\title{
Potential mechanisms behind physical exercise vs. epigenetic regulation for preventing breast cancer
}

\begin{abstract}
Breast cancer is the most commonly diagnosed cancer and has been the second leading cause of death due to cancer among women worldwide. It is a disease in which malignant (cancer) cells form in the tissues of the breast and become deadly when they metastasize, spreading to other organs or bones. Breast cancer is one of the major cancer diseases, occurring in both men and women, but it is rare in men. Though risk for breast cancer is affected by genetic factors, age, and other factors or personal habits; recent studies have suggested that physical exercise induces positive effects for lowering these risks as well as reducing the incidence rate. In the current review, we will look at previous studies, which have investigated links between physical exercise and breast cancer in the last decade. Meanwhile, we will discuss potential mechanisms by which physical exercise may play a role in preventing breast cancer, with special emphasis on a recent study on epigenetic regulations during physical exercise.
\end{abstract}

Volume 8 Issue 4 - 2017

\author{
Xiaojing Dai, ${ }^{3}$ Fan Yang, ${ }^{1,2}$ Xiaobing Shi, ${ }^{1,2,3}$ \\ Johnny Huard, ${ }^{4}$ Yong $\mathrm{Li}^{2,5,6}$ \\ 'Center for Stem Cell and Regenerative Medicine, University of \\ Texas Health Science Center at Houston (UTHealth), USA \\ ${ }^{2}$ Center for Tissue Engineering and Aging Research, University of \\ Texas Health Science Center at Houston (UTHealth), USA \\ ${ }^{3}$ Department of Traumatic Surgery, Tongji Hospital,Tongji \\ Medical College, China \\ ${ }^{4}$ Center for Cancer Epigenetics, University of Texas, USA \\ ${ }^{5}$ Department of Orthopaedic Surgery, McGovern Medical \\ School, USA \\ ${ }^{6}$ Center for Regenerative Sports Medicine, Steadman Philippon \\ Research Institute, USA \\ ${ }^{7}$ Department of Internal Medicine, McGovern Medical School, \\ USA
}

Correspondence: Yong Li, MD, PhD, 1825 Pressler Street, Houston, TX 77030, USA, Email Yong.li. I @uth.tmc.edu

Received: August 10,2017 | Published: August 22, 2017

\section{Introduction}

The incidence of patients with breast cancer is increasing every year. Breast cancer has recently been ranked as the second most common cancer in women, just after skin cancer in the U.S. However, death rates from breast cancer have been declining since 1990, due in part to better screening and early detection, increased awareness, and continually improving treatment options. In recent years, new applications in both diagnosis and treatment have gradually reduced female breast cancer incidence rates. ${ }^{1}$ Considering alternative prevention and therapeutic methods, physical exercise has recently been gaining increased attention in the clinic. Regular exercise appears to lower breast cancer risk by about 10-20 percent, which is a considerable impact from a non-pharmacologic intervention with no cost. Thus, the recently emerging field of exercise-oncology research will be expected to not only clarify the mechanisms behind prevention, but also shed light on future treatment for breast cancer. In this current review, we will summarize recent studies on physical exercise with respect to breast cancer, and discuss their relationship and possible underlying mechanisms.

\section{Risk factors for breast cancer}

Breast cancer is the second most common type of cancer and the leading cause of cancer-related death in women worldwide (link: https://www.breastfriends.org). It is a tremendous disease, affecting lifespan and healthspan. The incidence of breast cancer is increasing every year, and an estimated 252,710 new cases of invasive breast cancer are expected to be diagnosed in women in the U.S. in 2017 (link:http://www.breastcancer.org/symptoms/understand_bc/ statistics). Throughout the world, every year more than 400,000 deaths are caused by breast cancer and, out of these diagnosed cases, there is more than 2.8 million breast cancer survivors. ${ }^{2}$
Generally, there are two aspects of risk factors for breast cancer (see Table 1): (1) non-modifiable risk factors, which cannot be changed, such as gender. ${ }^{3,4}$ age $^{5-8}$ race and ethnicity, ${ }^{9,10}$, national development ${ }^{11-14}$ family history/biopsy. ${ }^{15-18}$ menstrual history, ${ }^{19-22}$ breast features ${ }^{23-25}$ blood type, ${ }^{26}$ personal disease history ${ }^{27-28}$ and genetic inherited changes $^{29}$ and (2) modifiable risk factors, such as reproductive history, ${ }^{30-33}$ breast feeding, ${ }^{34-38}$ exogenous hormone exposure ${ }^{39,43}$ radiation exposure ${ }^{44,45}$ delay in diagnosis ${ }^{46}$ operation or treatment, ${ }^{47-54}$ oral agents ${ }^{55-57}$ and lifestyle. ${ }^{58-67}$ There have been extensive studies indicating that avoidance of cancer modifiable risk factors may be helpful for preventing breast cancer incidence and mortality. ${ }^{68-70}$ On the other hand, due to genetic susceptibility influences, which are inherited and unchangeable; the non-modifiable factors are not easily controllable risks for breast cancer. Therefore, it is feasible to reduce the risk factors that are not inherited, but can be changed. Among these modifiable risk factors, physical exercise behaviors not only are beneficial for preventing all stages of cancer development ${ }^{71}$ but also are helpful to maintain a healthy weight and reduce risks for developing other diseases, such as cardiovascular disease, diabetes, and stroke. ${ }^{72}$ Furthermore, physical activity (PA) has been increasingly regarded as the non-pharmacologic intervention for many cancer patients to combat both the physiologic and psychological effects of cancer treatment. ${ }^{73}$ A recent World Health Organization (WHO) report shows that physical inactivity remains one of the most important risk factors for total cancer related mortality (responsible for $6 \%$ of total deaths) along with overweight and obesity (responsible for another 5\%). ${ }^{74}$

\section{Breast cancer and physical activity (PA)}

Physical exercise brings many benefits to our healthy and nonhealthy populations. Frequency of exercise not only directly plays a significant role in the prevention of breast cancer (incidence rate), control of breast cancer progression, and improvement of patient 
physical abilities and balance; but also indirectly minimizes fatigue and nausea and improves self-esteem and quality of life in breast cancer patients. ${ }^{75}$ Numerous epidemiologic studies have documented that PA can down-regulate factors that increase the risk of breast cancer, thus reducing incidence and mortality of breast cancer. ${ }^{76-79}$ In this review, we have summarized a collection of various populationbased studies on breast cancer and PA, and compared the beneficial effect of exercise on cancer such as the cancer type, duration, intensity, and timing of exercise (before diagnosis, after diagnosis, or during treatment) (Table 2). ${ }^{76-92}$

Table I Risk Factors for Breast Cancer

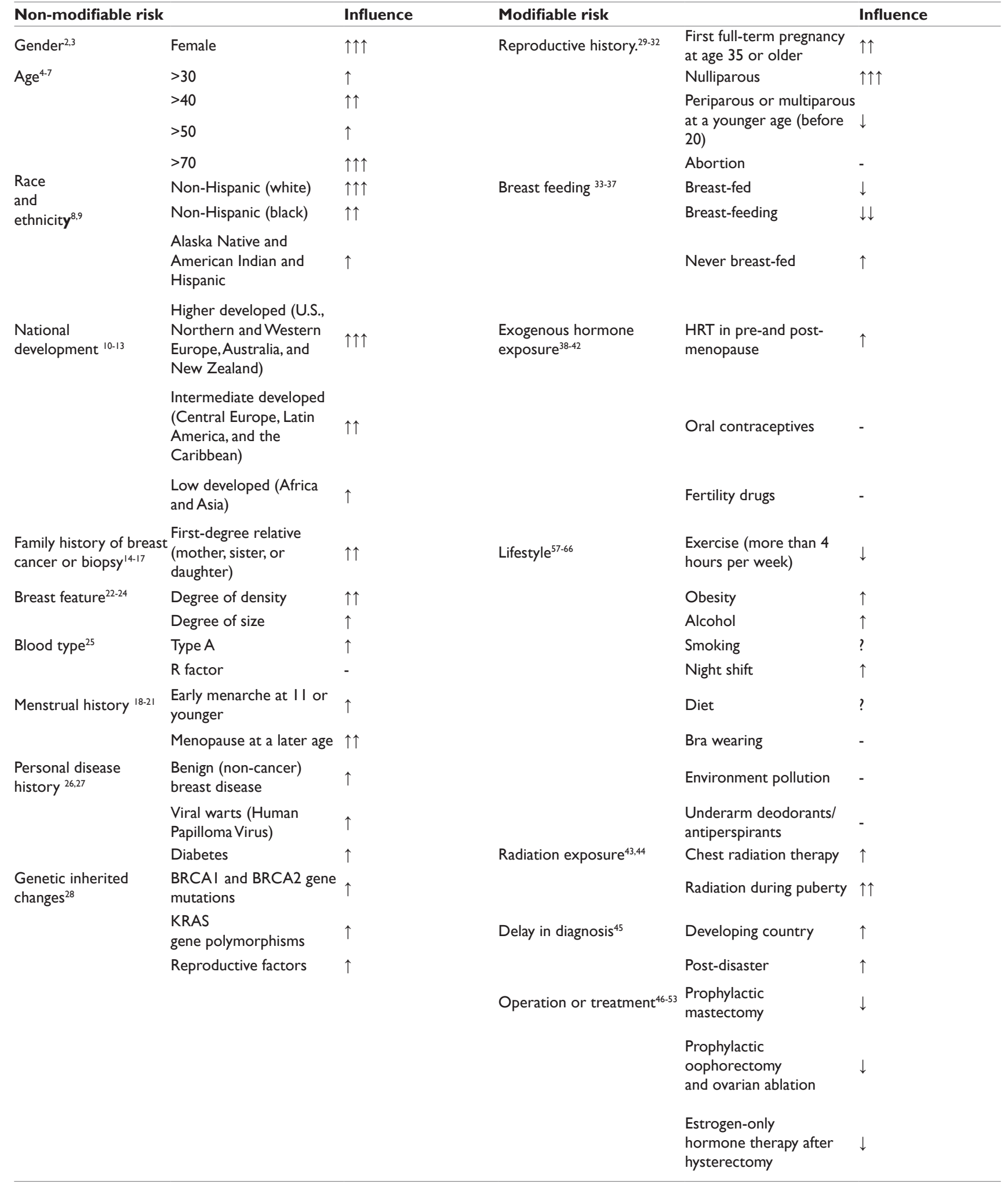


Table continued...

\begin{tabular}{|c|c|c|c|c|}
\hline Non-modifiable risk & Influence & Modifiable risk & & Influence \\
\hline & & & $\begin{array}{l}\text { Selective estrogen } \\
\text { receptor modulators } \\
\text { (SERMs) }\end{array}$ & $\downarrow$ \\
\hline & & & $\begin{array}{l}\text { Aromatase inhibitors and } \\
\text { inactivators }\end{array}$ & $\downarrow$ \\
\hline & & & Implant & - \\
\hline & & Oral agent ${ }^{54-56}$ & Vitamins & - \\
\hline & & & Statins & - \\
\hline & & & $\begin{array}{l}\text { Bisphosphonates(or } \\
\text { intravenous infusion) }\end{array}$ & - \\
\hline
\end{tabular}

$\uparrow$ upgrade; $\downarrow$ downgrade; - no influence; ? controversial.

Table 2 Summary of Breast Cancer and Physical Activity Studies

\begin{tabular}{|c|c|c|c|c|}
\hline Type of exercise & Sample & Timing of exercise & Relationship with BREAST CANCER & Reference \\
\hline Regular exercise & $\begin{array}{l}\text { a population-based survival study } \\
\text { among I,364 breast cancer cases } \\
\text { within the Norwegian Counties, } \\
\text { study was conducted during } \\
\text { I974-2005 }\end{array}$ & before diagnosis & $\begin{array}{l}\text { women with } \mathrm{BMI}<25 \mathrm{~kg} / \mathrm{m} 2 \text { had a } 66 \% \\
\text { reduction in overall mortality }\end{array}$ & Emau et al., 2010 \\
\hline Physical activity (PA) & $\begin{array}{l}\text { a total of I } 26 \text { women completed } \\
\text { the study ( } 60 \text { control/ } 66 \\
\text { intervention, } 61 \text { Hispanic/ } 65 \text { non- } \\
\text { Hispanic) }\end{array}$ & during treatment & $\begin{array}{l}\text { intervention group had a better impact during } \\
\text { PA }(P=0.03) \text { than controls }\end{array}$ & K. Crew et al., 2016 \\
\hline $\begin{array}{l}\text { PA } \\
>9 \text { 9ET-h/wk or } \\
\text { more ( } 3 \mathrm{~h} / \text { wk of } \\
\text { fast walking) }\end{array}$ & $\begin{array}{l}4,643 \text { women diagnosed } \\
\text { with invasive breast cancer } \\
\text { after entry into the Women's } \\
\text { Health Initiative study of } \\
\text { postmenopausal women }\end{array}$ & $\begin{array}{l}\text { before diagnosis and } \\
\text { after diagnosis }\end{array}$ & $\begin{array}{l}\text { PA had lower all-cause mortality both pre-and } \\
\text { post-diagnosis }\end{array}$ & Melinda L. Irwin et al., 20 I I \\
\hline Recreational PA & $\begin{array}{l}\text { I,264 women ages } 20 \text { to } 54 \\
\text { years who were diagnosed with } \\
\text { invasive breast cancer between } \\
1990 \text { and } 1992\end{array}$ & $\begin{array}{l}\text { at the time of } \\
\text { diagnosis }\end{array}$ & $\begin{array}{l}\text { reduced mortality among women who were } \\
\text { overweight or obese (BMI> } 25 \mathrm{~kg} / \mathrm{m} 2)\end{array}$ & Page E.Abrahamson et al., 2006 \\
\hline PA & $\begin{array}{l}\text { using prospective studies } \\
\text { published through June } 2013\end{array}$ & $\begin{array}{l}\text { before and after } \\
\text { diagnosis }\end{array}$ & $\begin{array}{l}\text { PA performed pre-/post-diagnosis is related to } \\
\text { reduced mortality risk among breast cancer }\end{array}$ & M. F. Leitzmann et al., 2013 \\
\hline Recreational PA & $\begin{array}{l}\text { a prospective cohort study in } \\
\text { Germany, including } 3,393 \text { non- } \\
\text { metastatic breast cancer patients } \\
\text { aged } 50-74 \text { years were assessed }\end{array}$ & before diagnosis & $\begin{array}{l}\text { inverse association of pre-diagnosis } \\
\text { recreational PA with mortality and recurrence } \\
\text { of breast cancer patient }\end{array}$ & Karen Steindorf et al.,20I3 \\
\hline PA & $\begin{array}{l}8 \text { studies }(12,108 \text { patients with } \\
\text { breast cancer) were included in } \\
\text { this meta-analysis }\end{array}$ & after diagnosis & $\begin{array}{l}\text { inverse relationship between PA and mortality } \\
\text { with breast cancer }\end{array}$ & Abdelaziz AlHomaidh et al., 20 I I \\
\hline Recreational PA & $\begin{array}{l}\text { population-based sampling } \\
\text { in Northern California, USA; } \\
\text { Ontario, Canada; Melbourne and } \\
\text { Sydney, Australia between I99I } \\
\text { and } 2000\end{array}$ & before diagnosis & $\begin{array}{l}\text { recreation PA was associated with lower risk } \\
\text { of death with estrogen receptor (ER)-positive, } \\
\text { but wasn't associated with all-cause mortality }\end{array}$ & Esther M. John et al., 2010 \\
\hline Regular exercise & $\begin{array}{l}\text { within Norwegian Counties, } \\
\text { study during 1974-2005 }\end{array}$ & before diagnosis & $\begin{array}{l}\text { women with } \mathrm{BMI}<25 \mathrm{~kg} / \mathrm{m} 2 \text { and age of } \\
\text { diagnosis }>55 \text { years had a } 66 \% \text { reduction in } \\
\text { overall mortality }\end{array}$ & Inger Thune et al., 2010 \\
\hline $\begin{array}{l}\text { Consistent long- } \\
\text { term participation } \\
\text { in PA }\end{array}$ & $\begin{array}{l}\text { California Teachers Study Cohort } \\
\text { members provided information } \\
\text { in I995-1996 on long-term } \\
\text { tracking }\end{array}$ & before diagnosis & $\begin{array}{l}\text { moderate and strenuous recreational PA } \\
\text { before breast cancer may lower risk of breast } \\
\text { cancer death }\end{array}$ & Huiyan Ma et al., 2009 \\
\hline $\begin{array}{l}\text { Both moderate and } \\
\text { vigorous intensity } \\
\text { recreational activity }\end{array}$ & $\begin{array}{l}\text { a cohort of I,23I women } \\
\text { diagnosed with breast } \\
\text { cancer between } 1995 \text { and } \\
\text { 1997conducted in Alberta, } \\
\text { Canada }\end{array}$ & after diagnosis & $\begin{array}{l}\text { both moderate and vigorous intensity } \\
\text { recreational activity decrease the risk of breast } \\
\text { cancer death }\end{array}$ & Kerry S. Courneya et al., 2009 \\
\hline PA & $\begin{array}{l}933 \text { women diagnosed with } \\
\text { local or regional breast cancer } \\
\text { between } 1995 \text { and } 1998\end{array}$ & after diagnosis & $\begin{array}{l}\text { increased PA of breast cancer women had a } \\
45 \% \text { lower risk of death }\end{array}$ & Leslie Bernstein et al., 2008 \\
\hline
\end{tabular}


Table continued...

\begin{tabular}{|c|c|c|c|c|}
\hline Type of exercise & Sample & Timing of exercise & Relationship with BREAST CANCER & Reference \\
\hline PA & $\begin{array}{l}\text { patients participants were cases } \\
\text { in Wisconsin, Massachusetts, and } \\
\text { New Hampshire between } 1988 \\
\text { and } 200 \text { I diagnosed with invasive } \\
\text { breast cancer }\end{array}$ & after diagnosis & $\begin{array}{l}\text { overall mortality and mortality from breast } \\
\text { cancer in women with breast cancer is } \\
\text { reduced in women engaged in PA }\end{array}$ & Walter C.Willett et al., 2008 \\
\hline $\begin{array}{l}\text { Long-term athletic } \\
\text { training }\end{array}$ & $\begin{array}{l}5,398 \text { living alumnae; } 2,622 \text { of } \\
\text { whom were former college } \\
\text { athletes and } 2,776 \text { were non- } \\
\text { athletes }\end{array}$ & before diagnosis & $\begin{array}{l}\text { Long-term athletic training may lower the risk } \\
\text { of breast cancer }\end{array}$ & M. Marguglio et al., 1985 \\
\hline PA & $\begin{array}{l}2,246 \text { women, including } 1,238 \\
\text { women with histologically- } \\
\text { confirmed breast cancer and } \\
\text { age-matched controls without } \\
\text { breast cancer from Pakistan }\end{array}$ & after diagnosis & $\begin{array}{l}\text { Lacking in PA and post-menopausal status were } \\
\text { found to have significant positive associations } \\
\text { with breast cancer }\end{array}$ & Hamid Rashid et al., 2016 \\
\hline $\begin{array}{l}\text { Physical self- } \\
\text { management } \\
\text { interventions }\end{array}$ & $\begin{array}{l}\text { A total of I } 3 \text { RCT'S representing } \\
2,180 \text { participants }\end{array}$ & during treatment & $\begin{array}{l}\text { physical self-management interventions during } \\
\text { breast cancer treatment as well as after the } \\
\text { primary treatment seem to generate beneficial } \\
\text { effects on quality of life }\end{array}$ & Nick Gerbruers et al., 2016 \\
\hline $\begin{array}{l}\text { 6-month exercise } \\
\text { program }\end{array}$ & $\begin{array}{l}85 \text { women for early-stage breast } \\
\text { cancer (stage I to III) }\end{array}$ & after diagnosis & $\begin{array}{l}\text { a reduction in depressive symptoms and lower } \\
\text { leukocyte, neutrophil, and lymphocyte counts } \\
\text { compared to control group }\end{array}$ & Robert E. Coleman et al., 2014 \\
\hline $\begin{array}{l}\text { Supervised exercise } \\
\text { and home exercise } \\
\text { group }\end{array}$ & 60 female breast cancer patients & after diagnosis & $\begin{array}{l}\text { decrease in interleukin- } 8 \text { and neutrophil- } \\
\text { activating protein- } 78 \text { levels in home exercise }\end{array}$ & Izmir \& R. USLU et al., 2013 \\
\hline
\end{tabular}

Numerous studies have suggested that PA prior to breast cancer diagnosis was significantly beneficial for the patient's treatment outcome and survival. ${ }^{76-92}$ For example, a group of researchers performed a prospective cohort study in Germany which included 3,393 non-metastatic breast cancer patients: the mortality of breast cancer was significantly and inversely associated with pre-diagnosis recreational PA. ${ }^{77}$. In addition, another similar study from Dr. Gammon and his colleagues demonstrated recreational PA prior to breast cancer diagnosis can improve patient survival. ${ }^{93}$. The cancer type, timing, and intensity of the PA are also important and should be taken into consideration. According to the 2008 Physical Activity (PA) Guidelines, it is recommended to engage in at least 2.5 hours per week of moderate-intensity PA (10 metabolic equivalent task (MET)hours/week, defined as 4 METs) to reduce the risk of cancer related morbidity and mortality. An enhanced epidemiological study from Jeannette and colleagues evaluated 13,000 breast cancer survivors in the After Breast Cancer Pool Project (ABCPP) from multiple cities in the U.S. and from Shanghai, China. ${ }^{94}$ After $18-48$ months postdiagnosis, they concluded that engaging in at least 10 MET-hours/ week of PA was associated with a $27 \%$ reduction in all-cause mortality and a $25 \%$ reduction in breast cancer mortality. Among these women, 1,508 had an initial breast cancer diagnosis between 1996 and 1997. ${ }^{94}$ and their ratio of physical activity (RPA) was classified according to their MET. A lower risk of all-cause death was observed for women who were engaged in an average of 9 or more MET-hours/week of PA, from menarche to diagnosis, when compared with women who did not exercise. This was also observed in menopausal status..$^{93}$ More recently, results from a systematic review and random-effects metaanalysis for pre- and post-diagnosis PA in relation to breast cancer mortality were reported. ${ }^{95}$ By Nov 2012, there were 31 studies with 63,786 cases reported with meta-analysis, and results suggested that the intensity of PA is strongly associated with risk of breast cancerrelated death. Additionally, 34 randomized controlled trials assessed the effects of PA using meta-analysis, and indicated that PA has a beneficial effect on the physiology, body composition, physical functions, psychological outcomes, and quality of life in patients after treatment for breast cancer. ${ }^{96}$
On the other hand, the studies also showed that lack of PA is associated with a higher breast cancer occurrence. A populationbased sampling in the U.S., Canada, and Australia was investigated with follow-up for $7-8$ years, and showed that patients engaging in recreational activity during the 3 years prior to diagnosis had a $34 \%$ lower risk of cancer-related death. It was estimated that about $7.9 \%$ of Canadian patient cancer cases (breast, colon, endometrium, prostate, lung, and ovarian) were associated with physical inactivity, demonstrating that thousands of cancer cases may be prevented by following a healthy lifestyle which includes PA. ${ }^{85}$ In a study from Norwegian Counties spanning from 1974 to 2005, 1,364 breast cancer patients were surveyed. Women with a body mass index (BMI) of $<25$ $\mathrm{kg} / \mathrm{m} 2$ and an age of diagnosis of $>55$ years had a $66 \%$ reduction in overall mortality if they exercised regularly before diagnosis compared to sedentary women. ${ }^{80}$ Another study from the California Teachers Association reported that patients engaging in high or intermediate levels of long-term PA had a lower risk of breast cancer-related death (RR, 0.53; 95\%CI, 0.35-0.80) than patients with low activity levels (RR, $0.63 ; 95 \% \mathrm{CI}, 0.45-0.93$ ). However, there are some reports that have suggest PA is not significantly associated with breast cancer mortality. An Italian multicenter, case-controlled study suggested that there was no significant relationship between survival after breast cancer emergence and several major lifestyle factors, including PA. ${ }^{97}$ These controversial results may be due to variations in the amount of PA and duration. One report from Irwin et al. found that women who participated in moderate-intensity recreational PA, such as brisk walking, post-diagnosis had a $64 \%$ lower risk of cancer-related death than inactive women. ${ }^{78}$ Hence, physical activity may not only lower the risk of breast cancer incidence but can influence survival after breast cancer diagnosis. ${ }^{77,97,98}$

\section{Potential mechanisms behind physical exercise for preventing breast cancer}

Physical exercise has been reported to have the potential to reduce risk of death from all stages of carcinogenesis (initiation, promotion, and progression). ${ }^{71}$ Previous studies have discussed that physical exercise may affect tumor initiation by enhancing the cytochrome 
P450 system and enhancing selective enzymes in the carcinogen detoxification pathway, such as glutathione-S-transferase. ${ }^{99}$ In addition, physical exercise may also prohibit promotion and progression stages of carcinogenesis by scavenging reactive oxygen species (ROS); ${ }^{100}$ altering cell proliferation, apoptosis, and differentiation; ${ }^{71}$ decreasing inflammation; ${ }^{101}$ and enhancing immune function and suppressing angiogenesis. ${ }^{99}$ With this complex information, we will sum up previous reports and discuss potential mechanisms behind the relationship between PA and breast cancer in several aspects, from whole body and the metabolic system to molecular pathways(Figure 1). ${ }^{102-105}$

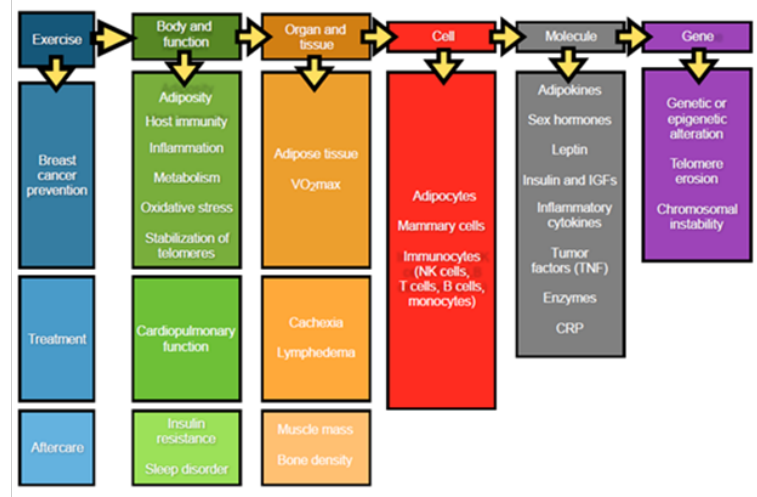

Figure I Potential mechanisms behind the relationship between PA and breast cancer in several aspects, from Whole body and the metabolic system to molecular pathways.

\section{Inflammatory reactions}

Treatment of cancer is related to disruption of immune system functions. ${ }^{106,107}$ Some studies have investigated whether exercise can modulate circulating proinflammatory cytokines, such as IL-1 $\beta$, IL-2, IL-4, macrophage inflammatory protein-1 beta (MIP-1 $\beta$ ), and tumor necrosis factor alpha (TNF- $\alpha),{ }^{92,108,109}$ suggesting a protective effect of exercise on inflammation perturbation following cancer treatment. A systematic review suggests that physical exercise can lead to changes in a variety of immune system parameters, including lymphocyte function such as improved cytotoxic activity by natural killer (NK) cells and proliferation of granulocytes. ${ }^{110}$ Moreover, Jones and his colleagues illustrated aerobic training cause's favorable alterations in metabolic and immune-inflammatory pathways. ${ }^{111}$ A more recent study showed that exercise training and tamoxifen reduced tumor IL-6 levels as well as NF-kB and STAT3 expression, and up-regulated TPM1 and PDCD4 expression $(P<0.05) .{ }^{112}$ Rogers et al. reported that exercise reduces pro-inflammatory serum cytokines through changes in body composition and, in turn, attenuates fatigue, improves sleep quality, and reduces the risk of cancer recurrence. ${ }^{113}$

There are controversial results among these studies with respect to immune system responses during or after exercise. It is possible that various results come from differences in physical exercise intensity and duration, as well as heterogeneous patient populations and differences in study methodology. ${ }^{114}$ However, it has been gradually accepted throughout the research community that the effects of physical exercise are beneficial to the immune system and its defense mechanisms with respect to cancer physiology and pathology processes. A previous study indicated that some acute exerciseinduced factors, such as IL-6 (interleukin 6), NGPTL-4 (angiopoietin like 4), MCP-1 (monocyte chemotactic protein-1 also known as CCL2), CX3CL1 (fractalkine), IL-8 (interleukin 8), IL-15 (interleukin 15), Irisin, and secreted protein acidic and rich in cysteine (SPARC) are produced locally in skeletal muscles during muscle contraction, and can be released into arterial blood. Furthermore, it has been reported that muscle-derived oncostatin M (OSM) and Irisin can decrease breast cancer cell viability, while SPARC inhibits tumorigenesis in the colon of exercising mice. ${ }^{115}$ Herein, we have summarized the effects of physical exercise on other aspects of the body and overall health, such as inflammatory adipose tissue metabolism ${ }^{103}$ sex hormones ${ }^{116}$ leptin ${ }^{102}$ and tumor factors, ${ }^{117}$ cardiopulmonary function, ${ }^{118-120}$ insulin resistance and sleep disorders ${ }^{120}$ cachexia and lymphedema2, muscle mass and bone density, ${ }^{121}$ and genetic alteration(Figure 1). ${ }^{122}$

\section{Epigenetic regulation}

Beyond the above-described metabolic impact of physical exercise on breast cancer, an emerging field of exercise-oncology research is poised to determine the efficacy of, and biological mechanisms by which, aerobic exercise affects cancer incidence, progression, and/ or metastasis. ${ }^{123}$ However, it is not clear what molecular mechanisms are involved and how physical exercise prevents or reduces incidence and mortality of different kinds of cancers. There is growing evidence suggesting that traits of trainability (the response to exercise training) might depend on epigenetics. Environmental effects, such as nutrition, diet, and exercise can alter epigenetic marks from either DNA methylation or post-translational modifications (acetylation, phosphorylation, and ubiquitination) of histones. ${ }^{124}$ One particular study suggests an indirect link between exercise and cardiovascular diseases through epigenetic modulation. ${ }^{124}$ It has also been reported that the myogenic genes in human skeletal muscle are altered by physical activity. ${ }^{125}$ In addition, it has been found that epigenetic regulation of the tumor suppressor gene, L3MBTL1, has a favorable impact on survival outcomes of breast cancer patients. ${ }^{126}$ However, how physical exercise affects oncogenes through alternating epigenetic regulation remains a question. It has been discovered that exercise results in aberrant DNA methylation patterns in tissues that have been extensively described as triggers for carcinogenesis. ${ }^{127}$ It has also been suggested that exercise and epigenetics activate an intricate mechanism that induces metabolic adaptation. ${ }^{72}$ Shock and colleagues also reported a possible exercise-induced methylation effect in mitochondrial genomes. ${ }^{128}$ At current, there are still controversial reports and discussions of the association between PA and DNA methylation. ${ }^{129-131}$ Therefore, it will be important to investigate the essential roles of epigenetic factors and regulation with respect to physical exercise and health benefits. Furthermore, certain challenging concepts need to be clarified, including how much the intensity and duration of physical exercise impacts the benefits of PA to provide the best effects on health, prevent aging, and decrease the incidence of cancers.

There are various mechanisms possibly associated with the benefits of exercise on epigenetic regulation in cancer prevention or treatment. Recently, ASC (apoptosis speck-like protein containing a CARD (caspase recruitment domain)) was investigated in apoptosis and tumor suppression. The gain- and loss-of-function of ASC in the study indicated an effect of promoter methylation on the regulation of TMS1 (target of methylation-induced silencing) in breast cancer and its essential role in docetaxel chemotherapy, suggesting potential benefits of ASC associated with cancer chemotherapy. ${ }^{132}$ From this study, compared to an older control (no exercise) group, the degree of ASC methylation was higher in an older exercise group with presumably lower ASC expression. Though chronic moderate exercise was also reported to modulate pro-inflammatory cytokines in the previous study, the detailed mechanism behind ASC in cancer is still under investigation. It has been reported that chronic 
moderate exercise appears to attenuate the age-dependent decrease in ASC methylation, implying there is suppression of excess proinflammatory cytokines through reduction of ASC expression. ${ }^{133}$ Beyond the protein alteration in tumor apoptosis and suppression, the physical stimulation/exercise of skeletal muscle also plays a critical role in mediating potential health benefits. ${ }^{117-120}$ Although the precise mechanism is not clear, chromatin remodeling through epigenetic histone modification has appeared as a critical regulatory mechanism that controls gene expression in general. ${ }^{125}$ Other accumulating data suggest that exercise of moderate intensity causes regulation of redox homeostasis and signaling, including generation of appropriate ROS levels. ${ }^{99,124}$ It is still unknown whether these factors might influence tumor progression, apoptosis, and metastasis. Exercise can also promote angiogenesis and knowing that the blood vessel walls contain a variety of stem cells (perivascular endothelial and mural cells). ${ }^{134-136}$ and some of these stem cells have recently been shown to have an inhibitory effect on cancer cells through unknown mechanisms, the beneficial effect of exercise on cancer development and prevention is maybe related to these blood vessel derived cells.

\section{Conclusion and perspectives}

Breast cancer accounts for $75 \%$ of all cancers and $15 \%$ of cancerspecific deaths amongst females. However, death rates from breast cancer have been falling year by year, mainly due to new technology for early detection and therapeutic development. Physical exercise is beneficial to breast cancer patients through all stages (prevention, diagnosis, and survival) via immune response mechanisms, metabolism, hormone regulation, insulin resistance, anti-oxidant enzymes, and epigenetic regulation. Another hot topic is investigation of biomarkers, which plays an essential role in the management of patients with invasive breast cancer. Biomarkers and diagnostic tools, such as Kir67, urokinase plasminogen activator (uOA)-PAI-1, Oncotype DX, MammaOrint, EndoPredic, Breast Cancer Index (BCI) and Prosigna (PAM50) may be used to predict outcome and aid in adjunct therapy according to guidelines from the European Group on Tumor Markers. ${ }^{137,138}$ Frequent exercise not only stimulates or modifies changes in both genes and proteins that are biomarkers for diagnosis of breast cancer, but also reduces risk factors and is associated with successful treatment outcomes for breast cancer. Therefore, physical exercise is capable of bringing the benefits of both prevention and treatment in breast cancer, and increases the survival of breast cancer patients.

\section{Acknowledgements}

The authors would like to thank Dr. Mary Hall for her excellent editing of this manuscript.

\section{Conflicts of Interest}

The authors declare that there is no conflict of interests regarding the publication of this paper.

\section{Funding}

None.

\section{References}

1. Li Z, Sergent F, Bolla M, Zhou Y, et al. Prognostic factors of second primary contralateral breast cancer in early-stage breast cancer. Oncal Lett. 2015;9(1):245-251.

2. Dieli Conwright CM. Exercise after breast cancer treatment :current perspectives. Breast cancer (Dove Med Press). 2015;7:353-362.
3. Ruddy KJ, Winer EP. Male breast cancer:risk factors, biology, diagnosis, treatment, and survivorship. Ann Oncol. 2013;24(6):1434-43.

4. Ban KA, Godellas CV. Epidemiology of Breast Cancer. Surg Onc Clin N Am. 2014;23(3):409-422.

5. Howlader N SEER. Cancer Statistics Review, 1975-2010. National Cancer Institute. Bethesda, USA. 2013.

6. De Santis CE. Breast Cancer Statistics 2015:Convergence of Incidence Rates Between Black and White Women. CA Cancer J Clin. 2016;66(1):31-42.

7. Kakarala M, Wicha MS. Implications of the cancer stem-cell hypothesis for breast cancer prevention and therapy. J Clin Oncol. 2008;26(17):2813-2820.

8. Coombs N J, Cronin KA, Taylor RJ, et al. The impact of changes in hormone therapy on breast cancer incidence in the US population. Cancer Causes Control. 2010;21(1):83-90.

9. American Cancer Society. Cancer Facts \& Figures. 2017. 2017.

10. Pfeiffer RM, Mitani A, Matsuno RK, et al. Racial differences in breast cancer trends in the United States (2000-2004). J Natl Cancer Inst. 2008;100(10):751-752.

11. Maxwell Parkin D. Cancers of the breast, endometrium and ovary:Geographic correlations. Eur $J$ Cancer Clin Oncol. 1989;25(12):1917-1925.

12. Kliewer EV, Smith KR. Breast cancer mortality among immigrants in Australia and Canada. J Natl Cancer Inst. 1995;87(15):1154-1161.

13. Corbex M, Bouzbid S, Boffetta P. Features of breast cancer in developing countries, examples from North-Africa. Eur J Cancer. 2014;50(10):1808-1818.

14. Torre LA. Global cancer statistics, 2012. CA Cancer J Clin. 2015;65(2):87-108.

15. Kotsopoulos J. Risk factors for ductal and lobular breast cancer: results from the nurses' health study. Breast Cancer Res. 2010;12(6):R106.

16. Goldacre MJ, Abisgold JD, Yeates DGR, et al. Benign breast disease and subsequent breast cancer:English record linkage studies. J Public Health (Oxf). 2010;32:565-571.

17. Kabat GC. A multi-center prospective cohort study of benign breast disease and risk of subsequent breast cancer. Cancer Causes Control. 2010;21(6):821-828.

18. Worsham MJ. Risk factors for breast cancer from benign breast disease in a diverse population. Breast Cancer Res. Treat. 2009;118(1):1-7.

19. Brinton LA, Schairer C, Hoover RN, et al. Menstrual factors and risk of breast cancer. Cancer Invest. 1988;6(3):245-254.

20. Hamajima N. Menarche, menopause, and breast cancer risk: Individual participant meta-analysis, including 118964 women with breast cancer from 117 epidemiological studies. Lancet Oncol. 2012;13(11):11411151.

21. Ritte R. Height Age at menarche and risk of hormone receptorpositive and -negative breast cancer: A cohort study. Int $J$ Cancer. 2013;132(11):2619-2629.

22. Smith PG, Doll R. Late effects of $X$ irradiation in patients treated for metropathia haemorrhagica. Br J Radiol. 1976;49(579):224-232.

23. Boyd NF. Mammographic density: a heritable risk factor for breast cancer. Methods in molecular biology. Clifton NJ. 2009;472:343-360.

24. Mc Cormack VA, dos Santos Silva I. Breast density and parenchymal patterns as markers of breast cancer risk:a meta-analysis. Cancer Epidemiol Biomarkers Prev. 2006;15(6):1159-1169. 
25. Boyd NF. Mammographic Density and the Risk and Detection of Breas Cancer. N Engl J Med. 2007;356(3):227-236.

26. Miao SY, Zhou W, Chen $\mathrm{L}$, et al. Influence of $\mathrm{ABO}$ blood group and Rhesus factor on breast cancer risk:A meta-analysis of 9665 breast cancer patients and 244768 controls. Asia Pac J Clin Oncol. 2013;10(2):101-108

27. Anothaisintawee T. Risk factors of breast cancer:a systematic review and meta-analysis. Asia Pacific J public Heal. 2013;25(5):368-387.

28. Luo J. Pre-existing diabetes and breast cancer prognosis among elderly women. Br J Cancer. 2015;113(5):827-832.

29. Cybulski C, Wokołorczyk D, Jakubowska A, et al. Risk of Breast Cance in Women With a CHEK2 Mutation With and Without a Family History of Breast Cancer. J Clin Oncol. 2017;29(28):3747-3752.

30. Lambe M. Transient increase in the risk of breast cancer after giving birth. N Engl J Med. 1994;331(1):5-9.

31. Gail MH. Projecting individualized probabilities of developing breast cancer for white females who are being examined annually. $J$ Natl Cancer Inst. 1989;81(24):1879-1886.

32. Anderson KN, Schwab RB, Martinez ME. Reproductive risk factors and breast cancer subtypes: A review of the literature. Breast Cancer Res Treat. 2014;144(1):1-10.

33. Vessey MP. Effect of endogenous and exogenous hormones on breast cancer: epidemiology. Verh Dtsch Ges Pathol. 1997;81:493-501.

34. Collaborative Group on Hormonal Factors in Breast Cancer. Breas cancer and breastfeeding: collaborative reanalysis of individual data from 47 epidemiological studies in 30 countries, including 50302 women with breast cancer and 96973 women without the disease. Lancet. 2002;360(9328):187-195.

35. Furberg H, Newman B, Moorman P, et al. Lactation and breast cancer risk. Int J Epidemiol. 1999;28(3):396-402.

36. Zhou Y. Association between breastfeeding and breast cancer risk:evidence from a meta-analysis. Breastfeed Med. 2015;10:175-82.

37. Chowdhury R. Breastfeeding and maternal health outcomes: a systematic review and meta-analysis. Acta Paediatr. 2015;104(467):96-113.

38. Group C, Factors H, Cancer B. Breast cancer and breastfeeding : collaborative reanalysis of individual data from 47 epidemiological studies in 30 countries, including 50302 women with breast cancer and 96973 women without the disease. Lancet. 2002;360(9328):187-195.

39. Grady D. Cardiovascular disease outcomes during 6.8 years of hormone therapy: Heart and Estrogen/progestin Replacement Study follow-up (HERS II). JAMA. 2002;288(1):49-57.

40. Freund R, Kelsberg G, Safranek S. Clinical Inquiry:do oral contraceptives put women with a family history of breast cancer at increased risk? $J$ Fam Pract. 2014;63(9):540-549.

41. Collaborative Group on Hormonal Factors in Breast Cancer. Breast cancer and hormonal contraceptives:Collaborative reanalysis of individual data on 53 297. Lancet. 1996;347(9017):1713.

42. Marchbanks PA.Oral contraceptives and the risk of breast cancer. $N$ Engl J Med. 2002;346(26):2025-2032.

43. Moorman PG, Havrilesky LJ, Gierish JM, et al. Oral Contraceptives and Risk of Ovarian Cancer and Breast Cancer Among High-Risk Women: A Systematic Review and Meta-Analysis. J Clin Oncol. 2013;31(33):4188-4198.

44. Terenziani M. Occurrence of breast cancer after chest wall irradiation for pediatric cancer, as detected by a multimodal screening program. Int J Radiat Oncol Biol Phys. 2013;85(1):35-39.
45. Ozaki A. Breast cancer patient delay in Fukushima, Japan following the 2011 triple disaster:a long-term retrospective study. BMC Cancer. 2017;17(1):423.

46. Colditz GA, Bohlke K, Berkey CS. Breast cancer risk accumulation starts early:Prevention must also. Breast Cancer Research and Treatment. 2014;145(3):567-579.

47. Eleje GU. Risk-reducing bilateral salpingo-oophorectomy in women with BRCA1 or BRCA2 mutations. Cochrane Database Syst Rev. 2016.

48. Rebbeck TR. Prophylactic oophorectomy in carriers of BRCA1 or BRCA2 mutations. N Engl J Med. 2002;346(21):1616-1622.

49. Carey LA. Race, Breast Cancer Subtypes, and Survival in the Carolina Breast Cancer Study. JAMA. 2006;295(21):2492-2502.

50. Kauff ND. Risk-reducing salpingo-oophorectomy for the prevention of BRCA1- and BRCA2-associated breast and gynecologic cancer:A multicenter, prospective study. J Clin Oncol. 2008;26(8):1331-1337.

51. Tamoxifen for early breast cancer:an overview of the randomised trials. Early Breast Cancer Trialists Collaborative Group. Lancet. 1998;351(9114):1451-1467.

52. Cuzick J, Forbes J, Edwards R, et al. First results from the Internationa Breast Cancer Intervention Study (IBIS-I):A randomised prevention trial. Lancet. 2002;360(9336):817-824.

53. Cuzick J, Sestak I, Bonanni B, et al. Selective oestrogen receptor modulators in prevention of breast cancer:an updated meta-analysis of individual participant data. Lancet. 2013;381(9880):1827-1834

54. Goss PE, Ingle JN, Alés-Martínez JE, et al. Exemestane for BreastCancer Prevention in Postmenopausal Women. $N$ Engl $\mathrm{J}$ Med. 2011;364(25):2381-2391.

55. Zhang SM, Cook NR, Albert CM, et al. Effect of combined folic acid, vitamin B6, and vitamin B12 on cancer risk in women:a randomized trial. JAMA. 2008;300(17):2012-2021.

56. Dale KM, Coleman CI, Henyan NN, et al. Statins and cancer risk:a meta-analysis. JAMA. 2006;295(5):74-80.

57. Hue TF, Cummings SR, Cauley JA, et al. Effect of Bisphosphonate Use on Risk of Postmenopausal Breast Cancer:results from the randomized clinical trials of alendronate and zoledronic acid. JAMA Intern Med. 2014;174(10):1550-1557.

58. Bernstein L, Henderson BE, Hanisch R, et al. Physical exercise and reduced risk of breast cancer in young women. J Natl Cancer Inst. 1994;86(18):1403-1408.

59. Friedenreich CM. Physical Activity and Cancer Prevention: From Observational to Intervention Research. Cancer Epidemiol Biomarkers Prev. 2001;10(4):287-301

60. Adams-Campbell LL, Rosenberg L, Rao RS, et al. Strenuous physical activity and breast cancer risk in African-American women. $J$ Natl Med Assoc. 2001;93(7-8):267-275.

61. Lahart IM, Metsios GS, Nevill AM, et al. Physical activity, risk of death and recurrence in breast cancer survivors:A systematic review and metaanalysis of epidemiological studies. Acta Oncol. 2015;54(5):635-654.

62. Morimoto LM, White E, Chen Z, et al. Obesity, body size, and risk of postmenopausal breast cancer:the Women's Health Initiative (United States). Cancer Causes Control. 2002;13(8):741-751.

63. James FR, Wootton S, Jackson A, et al. Obesity in breast cancer - What is the risk factor?. Eur J Cancer. 2015;51(6):705-720.

64. Hamajima N, Hirose K, Tajima K, et al. Alcohol, tobacco and breast cancer - collaborative reanalysis of individual data from 53 epidemiological studies, including 58,515 women with breast cancer and 95,067 women without the disease. Br J Cancer. 2002;87(11):1234 1245 . 
65. Scoccianti C, Lauby Secretan B, Bello PY, et al. Female Breast Cancer and Alcohol Consumption: A Review of the Literature. Am J Prev Med. 2014;46(3):S16-S25.

66. Hoyer AP, Grandjean P, Jorgensen T, et al. Organochlorine exposure and risk of breast cancer. Lancet. 1998;352(9143):1816-1820.

67. Forman MR, Winn DM, Collman GW, et al. Environmental exposures, breast development and cancer risk:Through the looking glass of breast cancer prevention. Reprod Toxicol. 2015;54:6-10.

68. Zhu G, Zhang X, Wang Y, et al. Effects of exercise intervention in breast cancer survivors:A meta-analysis of 33 randomized controlled trails. Onco Targets Ther. 2016;9:2153-2168.

69. Mercier J, Savard J, Bernard P. Exercise interventions to improve sleep in cancer patients:A systematic review and meta-analysis. Sleep Med Rev. 2012.

70. Volaklis KA, Halle M, Tokmakidis SP. Exercise in the prevention and rehabilitation of breast cancer. Wien Klin Wochenschr. 2013;125(1112):297-301.

71. Kruk J, Czerniak U. Physical activity and its relation to cancer risk:Updating the evidence. Asian Pacific $J$ Cancer Prev. 2013;14(7):3993-4003.

72. Pareja Galeano H, Sanchis Gomar F, García-Giménez JL, et al. Physical exercise and epigenetic modulation: Elucidating intricate mechanisms. Sport Med. 2014;44(4):429-436.

73. Friedenreich CM, Orenstein MR. Physical Activity and Cancer Prevention :Etiologic Evidence and Biological Mechanisms. J Nutr. 2002;132(11):3456S-3464S.

74. Psaltopoulou T, Ntanasis-Stathopoulos I, Tzanninis IG, et al. Physical Activity and Gastric Cancer Risk: A Systematic Review and MetaAnalysis. Clin J Sport Med. 2016;26(6):445-464.

75. Schwartz AL. Daily fatigue patterns and effect of exercise in women with breast cancer. Cancer Pract. 2000;8(1):16-24.

76. Ibrahim EM, Al Homaidh A. Physical activity and survival after breast cancer diagnosis: Meta-analysis of published studies. Med Oncol. 2011;28(3):753-765.

77. Schmidt ME, Chang-Claude J, Vrieling A, et al. Association of prediagnosis physical activity with recurrence and mortality among women with breast cancer. Int J Cancer. 2013;133(6):1431-1440.

78. Irwin ML, Smith AW, McTiernan A, et al. Influence of pre- and postdiagnosis physical activity on mortality in breast cancer survivors:The health, eating, activity, and lifestyle study. J Clin Oncol. 2009;26(24):3958-3964.

79. Holick CN, Newcomb PA, Trentham-Dietz A, et al. Physical activity and survival after diagnosis of invasive breast cancer. Cancer Epidemiol Biomarkers Prev. 2008;17(2):379-386.

80. Emaus A, Veierød MB, Tretli S, et al. Metabolic profile, physical activity, and mortality in breast cancer patients. Breast Cancer Res Treat. 2010;121(3):651-660.

81. Greenlee H, Molmenti CL, Crew KD, et al. Survivorship care plans and adherence to lifestyle recommendations among breast cancer survivors. J Cancer Surviv. 2016;10(6):956-963.

82. Irwin ML, McTiernan A, Manson JE, et al. Physical activity and survival in postmenopausal women with breast cancer: Results from the women's health initiative. Cancer Prev Res. 2011;4(4):522-529.

83. Abrahamson PE, Gammon MD, Lund MJ, et al. Recreational physical activity and survival among young women with breast cancer. Cancer. 2006;107(8):1777-1785.

84. Schmid D, Leitzmann M. Association between physical activity and mortality among breast cancer and colorectal cancer survivors: a systematic review and meta-analysis. Ann Oncol. 2009;25(7):12931311 .
85. Keegan TH, Milne RL, Andrulis IL, et al. Past recreational physical activity, body size, and all-cause mortality following breast cancer diagnosis: Results from the breast cancer family registry. Breast Cancer Res Treat. 2010;123(2):531-542.

86. West-Wright CN, Henderson KD, Sullivan-Halley J, et al. Long-term and recent recreational physical activity and survival after breast cancer: The California teachers study. Cancer Epidemiol Biomarkers Prev. 2009;18(11):2851-2859.

87. Friedenreich CM, Gregory J, Kopciuk KA, et al. Prospective cohort study of lifetime physical activity and breast cancer survival. Int $J$ Cancer. 2009;124(8):1954-1962.

88. Frisch R, Wyshak G, Albright NL, et al. Lower prevalence of breast cancer and cancers of the reproductive system among former college athletes compared to non-athletes. Br J Cancer. 1985;52(6):885-891.

89. Bano R, Ismail M, Nadeem A, et al. Potential Risk Factors for Breast Cancer in Pakistani Women. Asian Pac J Cancer Prev. 2016;17(9):43074312.

90. Van Dijck S, Nelissen P, Verbelen H, et al. The effects of physical selfmanagement on quality of life in breast cancer patients: A systematic review. Breast. 2016;28:20-28.

91. Saxton JM, Scott EJ, Daley AJ, et al. Effects of an exercise and hypocaloric healthy eating intervention on indices of psychological health status, hypothalamic-pituitary-adrenal axis regulation and immune function after early-stage breast cancer: a randomised controlled trial. Breast Cancer Res. 2014;16(2):R39.

92. Ergun M, Eyigor S, Karaca B, et al. Effects of exercise on angiogenesis and apoptosis-related molecules, quality of life, fatigue and depression in breast cancer patients. Eur J Cancer Care (Engl). 2013;22(5):626637

93. Cleveland RJ, Eng SM, Stevens J, et al. Influence of prediagnostic recreational physical activity on survival from breast cancer. Eur $J$ Cancer Prev. 2012;21(1):46-54.

94. Beasley JM, Kwan ML, Chen WY, et al. Meeting the physical activity guidelines and survival after breast cancer:Findings from the after breast cancer pooling project. Breast Cancer Res Treat. 2012;131(2):637-643.

95. Behrens G, Jochem C, Keimling M, et al. The association between physical activity and gastroesophageal cancer:Systematic review and meta-analysis. Eur J Epidemiol. 2014;29(3):151-170.

96. Fong DY, Ho JW, Hui BP, et al. Physical activity for cancer survivors:meta-analysis of randomised controlled trials 2012. Dal Maso L, Zucchetto A, Talamini R, et al. Effect of obesity and other lifestyle factors on mortality in women with breast cancer. Int J Cancer. 2008;123(9):2188-2194.

97. Enger SM, Bernstein L. Exercise activity, body size and premenopausal breast cancer survival. Br J Cancer. 2004;90(11):2138-2141.

98. Radak Z, Zhao Z, Koltai E, et al. Oxygen consumption and usage during physical exercise: the balance between oxidative stress and ROS-dependent adaptive signaling. Antioxid Redox Signal. 2013;18(10):1208-1246.

99. Powers SK, Jackson MJ. Exercise-induced oxidative stress:cellular mechanisms and impact on muscle force production. Physiol Rev. 2010;88(4):1243-1276.

100. Coussens L M, Werb Z. Inflammation and cancer. Nature. 2002;420(6917):860-867

101. Schmidt S, Monk J M, Robinson L E, et al. The integrative role of leptin, oestrogen and the insulin family in obesity-associated breast cancer: Potential effects of exercise. Obes Rev. 2015;16(6):473-487

102. Gleeson M, Bishop, Nicolette C, et al. The anti-inflammatory effects of exercise:mechanisms and implications for the prevention and treatment of disease. Nat Rev Immunol. 2011;11(9):607-615. 
103. Pinto A, Di Raimondo D, Tuttolomondo A, et al. Effects of physical exercise on inflammatory markers of atherosclerosis. Curr Pharm Des. 2012;18(28):4326-4349.

104. Coen P M, Flynn M G, Markofski M M, et al. Adding exercise to rosuvastatin treatment:Influence on $\mathrm{C}$-reactive protein, monocyte tolllike receptor 4 expression, and inflammatory monocyte (CD14+CD16+) population. Metabolism. 2010;59(12):1775-1783.

105. Banchereau J, A Karolina Palucka, et al. Immune and clinical responses in patients with metastatic melanoma to CD34+ progenitor-derived dendritic cell vaccine. Cancer Res. 2001;61(17):6451-6458.

106. Fairey A S, Kerry S Courneya, Catherine J Field, et al. Randomized controlled trial of exercise and blood immune function in postmenopausal breast cancer survivors. J Appl Physiol. 2005;98(4):1534-1540.

107. Jones L W, Diane R Fels, Miranda West, et al. Modulation of circulating angiogenic factors and tumor biology by aerobic training in breast cancer patients receiving neoadjuvant chemotherapy. Cancer Prev Res. 2013;6(9):925-937.

108. Koelwyn, G J, Jones L W, Moslehi J. Unravelling the causes of reduced peak oxygen consumption in patients with cancer: Complex, timely, and necessary. J Am Coll Cardiol. 2014;64:1320-1322.

109. Kruijsen Jaarsma M, Revesz D, Bierings M B, et al. Effects of exercise on immune function in patients with cancer:A systematic review. Exerc Immunol Rev. 2013;19:120-143.

110. Glass O K, Inman B A, Broadwater G, et al. Effect of aerobic training on the host systemic milieu in patients with solid tumours: An exploratory correlative study. Br J Cancer. 2015;112(5):825-831.

111. Khori V, Amani Shalamzari S, Isanejad A, et al. Effects of exercise training together with tamoxifen in reducing mammary tumor burden in mice: Possible underlying pathway of MIR-21. Eur J Pharmacol. 2015;765:179-187.

112. Rogers L Q, Fogleman A, Trammell R, et al. Effects of a physical activity behavior change intervention on inflammation and related health outcomes in breast cancer survivors: pilot randomized trial. Integr Cancer Ther. 2013;12(4):323-335.

113. Lee-Jones C, Humphris G, Dixon R, et al. Fear of cancer recurrence - A literature review and proposed cognitive formulation to explain exacerbation of recurrence fears. Psychooncology. 2013;6(2):95-105.

114. Aoi W, Naito Y, Takagi T, et al. A novel myokine, secreted protein acidic and rich in cysteine (SPARC), suppresses colon tumorigenesis via regular exercise. Gut. 2013;62(6):882-889.

115. Tworoger S S, Rosner B A, Willett W C, et al. The combined influence of multiple sex and growth hormones on risk of postmenopausal breast cancer : a nested case-control study. Breast Cancer Res. 2012;13(5):110

116. Kang DW, Lee J, Suh SH, et al. Effects of Exercise on Insulin, IGF Axis, Adipocytokines, and Inflammatory Markers in Breast Cancer Survivors : A Systematic Review and Meta-analysis. Cancer Epidemio Biomarkers Prev. 2017;26(3):355-366.

117. Jones L W, Alfano C M. Exercise oncology research:Past, present, and future. Acta Oncol. 2013;52(2):195-215.

118. Adraskela K, Veisaki E, Koutsilieris M, et al. Physical Exercise Positively Influences Breast Cancer Evolution. Clin. Breast Cancer. 2017;8209(16):30357-30363.

119. Scott J M, Adams S C, Koelwyn G J, et al. Cardiovascular Late Effects and Exercise Treatment in Breast Cancer : Current Evidence and Future Directions CVD-Cancer Continuum. Can J Cardiol. 2016;32(7):881890.
120. Zhu G, Zhang X, Wang Y, et al. Effects of exercise intervention in breast cancer survivors : a meta-analysis of 33 randomized controlled trails. Onco Targets Ther. 2016;9:2153-2168.

121. Colditz G A, Bohlke K. Priorities for the Primary Prevention of Breast Cancer. CA Cancer J Clin. 2014;64(3):186-194.

122. Ashcraft KA, Peace RM, Betof AS, et al. Efficacy and Mechanisms of Aerobic Exercise on Cancer Initiation, Progression, and Metastasis: A Critical Systematic Review of In Vivo Preclinical Data. Cancer Res. 2016;76(14):4032-4050.

123. Whayne TF. Epigenetics in the development, modification, and prevention of cardiovascular disease. Mol Biol Rep. 2015;42(4):765776.

124. Mcgee SL, Fairlie E, Garnham AP, et al. Exercise - induced histone modifications in human skeletal muscle. J Physiol. 2009;587(Pt 24):5951-5958.

125. Zeng H, Irwin ML, Lu L, et al. Physical activity and breast cancer survival: An epigenetic link through reduced methylation of a tumor suppressor gene L3MBTL1. Breast Cancer Res Treat. 2012;133(1):127135.

126. You J S \& Jones P A. Cancer Genetics and Epigenetics:Two Sides of the Same Coin? Cancer Cell. 2012;22(1):9-20.

127. Shock LS, Thakkar PV, Peterson EJ, et al. DNA methyltransferase 1, cytosine methylation, and cytosine hydroxymethylation in mammalian mitochondria. Proc Natl Acad Sci U S A. 2011;108(9):3630-3635.

128. Yuasa Y, ML Nagasaki H, Akiyama Y, et al. DNA methylation status is inversely correlated with green tea intake and physical activity in gastric cancer patients. Int J Cancer. 2009;124(11):2677-2682.

129. Slattery, Edwards S, Murtaugh M A, et al. Physical Activity and Breast Cancer Risk Among Women in the Southwestern United States. Ann Epidemiol. 2007;17(5):342-353.

130. Wanajo A, Sasaki A, Nagasaki H, et al. Methylation of the Calcium Channel-Related Gene, CACNA2D3, Is Frequent and a Poor Prognostic Factor in Gastric Cancer. Gastroenterology. 2008;135(2):580-590.

131. Gordian E, Ramachandran K, Singal R. Methylation mediated silencing of TMS1 in breast cancer and its potential contribution to docetaxe cytotoxicity. Anticancer Res. 2009;29(8):3207-3210.

132. Nakajima K, Takeoka M, Mori M, et al. Exercise effects on methylation of ASC gene. Int J Sports Med. 2010;31(9):671-675.

133. Leosco D Exercise promotes angiogenesis and improves b-adrenergic receptor signalling in the post-ischaemic failing rat heart 385-394. 2008 .

134. Cecilie Morland, Krister A Andersson, Øyvind P Haugen, et al. Exercise induces cerebral VEGF and angiogenesis via the lactate receptor HCAR1. 2017;15557:1-9.

135. Yu Q C, Song W, Wang D, et al. Identification of blood vascular endothelial stem cells by the expression of protein $\mathrm{C}$ receptor. Cell Res. 2016;26(10):1079-1098.

136. Bertoli G, Cava C, Castiglioni I. The ranostics MicroRNAs: New Biomarkers for Diagnosis, Prognosis, Therapy Prediction and Therapeutic Tools for Breast Cancer. Theranostics. 2015;5(10):11221143.

137. Nassar F J, Nasr R, Talhouk R. Pharmacology \& Therapeutics MicroRNAs as biomarkers for early breast cancer diagnosis, prognosis and therapy prediction. Pharmacol Ther. 2017;172:34-49. 